\title{
Abstract/Résumé analytique
}

\section{"I will never consent to be wedded with you!": Coerced Marriage in the Courts of Medieval England}

\author{
Sara M. Butler
}

This paper asks us to rethink the boundaries between consent and coercion in medieval England. From gentle persuasion to threats and abuse, coercion was a part of the courtship process. Although late medieval society expected parents to play an active, even heavy-handed, role in matchmaking. the English church recognized the possibility that parents might cross the line between influence and force, and consequently permitted annulments on these grounds. What happened when it was not the parents, but an overly zealous suitor who coerced a marriage? Very few Englishwomen brought suits of force and fear against their husbands. Those few documented cases of coerced marriage that have survived from the York cause papers of the later Middle Ages reveal how the victims perceived their own situations, and the ways litigants used the church courts to address these concerns.

Dans cet article, on nous demande de repenser aux limites entre le consentement et la contrainte dans l'Angleterre médiévale. De douce persuasion aux menaces et abus, la contrainte fit partie de la démarche des fréquentations. Quoique la société de la fin du Moyen-Âge s'attendait à ce que les parents jouent un rôle actif, voire même agressif dans le rôle d'entremetteurs, l'Église anglicane admettait la possibilité que les parents pourraient dépasser les bornes entre l'influence et la force et c'est pourquoi elle permettait les annulations pour cette raison. Qu'arriva-t'il lorsque ce n'était pas les parents mais un prétendant trop zélé qui contraignait au mariage? Très peu de femmes anglaises engagèrent des poursuites contre leurs maris à cause de violence ou de peur. Le peu de documents des procès qui ont survécu des causes de la cour d'York de la fin du Moyen-Âge nous révèlent comment les victimes percevaient leurs propres situations et comment les plaideurs se servaient de l'église pour aborder ces problèmes. 


\section{"I WILL NEVER CONSENT TO BE WEDDED WITH YOU!": COERCED MARRIAGE IN THE COURTS OF MEDIEVAL ENGLAND." 1}

By the time Isabel Grene of Yorkshire's bill of complaint reached the ears of the chancellor's officials in the later years of the fifteenth century, she had found herself in a position seemingly without remedy by normal procedures of the common law. Adopting the humble tone required of a bill in Chancery, she wrote:

Mekely besechith your pour Oratrice Isabell Grene Wedewe. Where as one Robert Daweson hath taken divers accions of dette and trespas ayenst yor said Oratrice at Kyngeston uppon Hull in which accions the said Robert at all suche tymes when xii men shuld appere he fallith nonnsued and so wrongfully vexeth and troubleth dayly your said Oratrice at her grete costes it is so graceous lord that the said Robert hathe long tyme proposid to marye with your said Oratrice be cause of certayn godes and lyvelode that she hath of her owne and she therto in no wise woll assent nowe late hath taken a newe accion of trespas ayenst her afore the shiref of the said toun and proposeth to have her condempned in the same ayenst all right and gode conscience. ${ }^{2}$

Robert's choice of victims underscores the vulnerability of propertied women in late medieval England. ${ }^{3}$ Without a husband or other male relatives to protect her, Isabel was an ideal target. The appearance of similar cases in the records of

1 Funding for this research was generously provided by the Social Sciences and Humanities Research Council of Canada. I am also indebted intellectually to the following persons for their comments on earlier drafts of this paper: C.J. Neville, Charles Donahue, Jr., Melissa Furrow, and also the anonymous reviewers for this journal. Finally, I would like to thank Ilana Krug for her generous assistance with some difficult Latin passages in Borthwick Institute, York (cited hereafter as BIY) CP. F 257.

2 Public Record Office, London (cited hereafter as PRO) C1/46/171, Isabel Grene, widow $c$. the Sheriffs of Hull (circa 1467 to 1470).

3 For a discussion of the vulnerability of wealthy widows, see Sue Sheridan Walker, "Litigation as Personal Quest: Suing for Dower in the Royal Courts, 1272-1350," in her Wife and Widow in Medieval England (Ann Arbor, 1993), pp. 81-108. 
Chancery suggests that this may have been a familiar ploy for young men wishing to get ahead in the world. For example, Joan Halstead of Bury St Edmunds, Suffolk, found herself in the same situation. Unable to take no for an answer, John Morley initiated several false actions of debt and trespass against her. Faced with a prison sentence for offences she had not committed, Joan turned to the chancellor for help. ${ }^{4}$ Before marrying her current husband, Agnes wife of Robert Raphaels underwent similar trauma at the hands of Hugh Oversall of Kingston upon Hull. Hugh spotted the opportunity for profit after Agnes's first husband died and she came into her dower rights. "[C]raftely and disceytfully" he laboured for her hand in marriage, "which she utterly denyed and refused." Incensed by her rejection and determined to find "sucor and advantage" he cautioned Agnes that unless "she would gyff hym large money att hys pleasour" he would force her into marriage by falsely claiming she had handfasted (that is, exchanged marriage vows) with him. Agnes reported that she was "in such fere and dreade that she, to be in rest and without trowble and have a release of hym, suffred hym to take of her a last of mutton talowe which as then was worthe xii li of Englisshe money," even though she had not exchanged vows with him. Only after she later married Robert Raphaels did she work up the courage to take action against the thieving mariner. ${ }^{5}$

These three tales of abuse highlight the difficulties women of property in medieval England encountered when faced with abusive suitors. Isabel, Joan, and Agnes were not willing to be passive victims of deceitful manipulation of the legal system. But how many women were, simply because they believed they had no other option open to them? Like Agnes, many women probably paid their extortionist-suitors in the hope of being rid of them for good. It is not hard to imagine, however, that, out of "fere and dreade," feeling they had no other choice, some women actually succumbed to these threats and exchanged vows with their aggressive suitors. The piteous examples of these three women pinpoint one of the greatest pitfalls of medieval marriage in English society: without control over their own property, wives might become a means to make money rather than objects of affection. The appearance of these women fending off gold diggers in the English court of Chancery was a tacit admission that, although the vulnerability of women in this respect was recognized, the abuse that might be directed against them generally was not.

The goal of this paper is to provide a reasonable answer to this predicament: if a woman did find herself the victim of coerced marriage, what were her legal options? The first part of this paper will examine the theory of the law, exploring the various legal options (both ecclesiastical and royal) available to victims of non-consensual marriage, and highlighting the blurring of boundaries, within the law, between consent and coercion. The second part of this paper will ana-

4 PRO C1/140/35, Joan Halsted of Bury St. Edmunds (circa 1504 to 1509). Certiorari (that is, a decision by chancery to hear an appeal from a lower court).

${ }^{5}$ PRO Cl/353/42, Robert Raphaels and Agnes his wife $c$. Hugh Oversall of Kingston on Hull, mariner (circa 1504 to 1509). 
lyze case studies, drawn primarily from the York cause papers (records of matrimonial litigation from the northern ecclesiastical province), but one also from the king's court. Each of these cases focuses on a woman who, through force and coercion, was compelled into marriage by an overly aggressive suitor. The surviving records of these cases help to shed light on both official and popular perceptions of coercion in medieval England. Moreover, by highlighting the legal options that women pursued in practice, they attempt to explain why victims of coerced marriage did not frequently turn to the law as a resolution for their problems.

\section{The Theory of the Law: Legal Options for Victims of Coerced Marriage}

Because marriage was a sacrament, coercion of this nature necessarily fell under the jurisdiction of the church courts. Matrimonial litigation revolving around allegations of the canonical impediment of force and fear, however, usually concerned youths or the underaged who had suffered intimidation at the hands of their parents or guardians. ${ }^{6}$ Although late medieval canon law held that only the consent of the couple was necessary for a valid marriage, parental involvement remained an important part of medieval marriage rituals. ${ }^{7}$ Cases of parental coercion in the ecclesiastical courts are very instructive about the marriage process and the legal options available to victims of coercion. The records suggest that, at times, parental involvement in spousal selection extended to threats and physical violence. For example, when Agnes Frankysh daughter of Robert Frankysh informed her parents that she did not wish to marry Thomas Taverner de Berewyk of Pontefract, her father beat her severely with a staff until she was brought around to his way of thinking. ${ }^{8}$ Similarly, Alice Bellamy's father threatened to take her by the ears and throw her into a pool if she did not marry as he wished. ${ }^{9}$ When money was the primary concern, the potential for abuse was even more explosive. Such was the case of Agnes Stelk who was beaten up and down

${ }^{6}$ For a discussion of impediments to marriage, see R.H. Helmholz, Marriage Litigation in Medieval England (Cambridge, 1972), chapter 3.

${ }^{7}$ For a discussion of parental involvement in medieval marriages, see Shannon McSheffrey, "'I Will Never Have None Ayenst My Faders Will': Consent and the Making of Marriage in the Late Medieval Diocese of London," in Constance M. Rousseau and Joel T. Rosenthal (eds.), Women, Marriage, and Family in Medieval Christendom: Essays in Memory of Michael M. Sheehan, C.S.B. (Kalamazoo, 1998), pp. 153-74; P.J.P. Goldberg, "“For Better, For Worse': Marriage and Economic Opportunity for Women in Town and Country," in P.J.P. Goldberg (ed.), Woman is a Worthy Wight: Women in English Society, c. 1200-1500 (Wolfeboro Falls, New Hampshire, 1992), pp. 108-25. For a discussion of consent theory in general, see Charles Donahue, Jr., "The Policy of Alexander the Third's Consent Theory of Marriage," in S. Kuttner (ed.), Proceedings of the Fourth International Congress of Mediaeval Canon Law (Vatican City, 1976), pp. 251-81.

${ }^{8}$ BIY CP. F 223 (1441).

${ }^{9}$ BIY CP. E 85 (1355). 
the sides of her body, threatened, and terrorized by her guardian until she agreed to the marriage partner he had chosen for her. ${ }^{10}$

Unhappy persons in this situation did have at least one option for release available to them. Since the twelfth century, the church had argued that "where they each do not consent, there is no marriage."11 Accordingly, force and fear were among the few grounds for annulment permitted by the medieval church. The difficulty, however, lay in determining whether a defendant had used sufficient force to warrant breaking the bond. This was no easy task. Thomas of Chobham, author of a thirteenth-century confessional manual on penance, addressed this issue directly in his work. He argued that the degree of force must be enough to weaken a steadfast man (constans vir). Also, it must be a physical fear; the threat of economic deprivation was not sufficient coercion to nullify consent. ${ }^{12}$ A cursory examination of English cases reveals that this prescription did not necessarily reflect actual practice. When Margaret daughter of Stephen Dawyng of Easingwold expressed unhappiness with her impending union, her father replied that "thou shall never have penyworth of goodes of myne and thou shall have goddis malisoun and mynn" unless she agreed to the marriage; nonetheless, the court's officials granted an annulment. ${ }^{13}$ The decision of the court in this case implies that Chobham's idealistic vision failed to recognize the frightening reality. Physical abuse can leave scars; economic abuse, on the other hand, can lead to desperation and eventual ruin.

Despite all of these obstructions and complexities, force was a relatively common defence in surviving record. Eleven per cent of the fourteenth-century and 13 per cent of the fifteenth-century cases of marriage litigation heard by the Archbishop of York's consistory court were defences of force. ${ }^{14}$ If we add to that data the number of underage marriages (which also demonstrate parental force even though this was not the specific defence presented), the figures rise substantially to include an additional 8 per cent for the fourteenth century and 4 per cent for the fifteenth. ${ }^{15}$ Finally, if we count as one all cases in which defences of both types were employed simultaneously, we arrive at a total of 12 per cent of matrimonial cases in the fourteenth century and 16 per cent of those in the fifteenth century in which one (or both) of the litigants alleged that they had been compelled into marriage against their will. ${ }^{16}$ Such high figures make it impossible to

${ }^{10}$ Canterbury Cathedral Archives (cited hereafter as "Canterbury") X.10.1, fos 29-31.

11 "ubi non est consensus utriusque, non est coniugium." Gratian, Emil Friedberg (ed.), Decretum (Leipzig, 1879), Causa. 30, quaestio 9.2, canon 1.

12 Thomas Chobham (ed. F. Broomfield), Thomae de Chobham. Summa Confessorum in Analecta Medieavalia Namurcensia, vol. 25, (Lousvain, 1968), p. 142.

13 BIY CP. F 268 (1486).

14 Charles Donahue, Jr. "Female Plaintiffs in Marriage Cases in the Court of York in the Later Middle Ages," in Sue Sheridan Walker (ed.), Wife and Widow in Medieval England (Ann Arbor, 1993), pp. 187, 189.

15 Ibid., p. 189.

16 Ibid. 
argue that the medieval English based marriage on individual consent alone; economics, status, and political alliances formed a powerful trinity of marital considerations. Even more instructive, however, is what these figures conceal. These percentages represent only suits brought before the consistory court. They do not reflect instances of forced marriage in which the couple simply acquiesced to the demands of their parents, nor do they reflect couples who solved the problem themselves by simply "self-divorcing" later in life, a practice that was seemingly fairly common. ${ }^{17}$ In a society where marriage inevitably meant the exchange of property, these figures probably do not reflect the total numbers of individuals compelled into marriage. Richard Helmholz has argued that provisions for impediment to marriage of force and fear are an "index to the mentality of the times." 18 Given the overwhelmingly economic nature of medieval marriage, coercion in various degrees (from gentle persuasion to threats and abuse) was an element of the courtship process in medieval English society: "Marriage was simply too important a matter to be left in the hands of emotional youth." 19 Thus, some degree of coercion was acceptable, even anticipated. P.J.P. Goldberg has argued that it was only "the most determined" who were "able to withstand the full force of parental opposition in the knowledge that canon law was on their side." 20 What is more, "[t]he headstrong girl marrying for love alone, against the desires of her family, did not win the approval of the canonists for upholding the ideal of free consent in marriage. She was within her rights, and she should incur no penalty or punishment, but she was acting against a legitimate authority." 21 This approach is underscored by the literature of the time. Both religious and educational writers "insisted that the fifth commandment, with its absolute injunction on children to obey their fathers and mothers, included parental control over their marriages." 22 Such a conservative interpretation of the "free consent" clause, then, emphasizes that many daughters in medieval England expected to experience some form of coercion during the marriage process, particularly if they were unwilling to comply with their family's choice of a suitor.

When a suitor compelled a grown woman to marry with threats and physical force, however, it was a much different situation. This kind of coercion lacked the respectability and influence of the family hierarchy. Understandably,

17 "Self-divorce" implies mutual abandonment without recourse to the law. For a discussion of self-divorce, see Helmholz, Marriage Litigation in Medieval England, p. 105.

18 Helmholz, Marriage Litigation, p. 90.

19 Bjorn Bandlien, "The Church's Teaching on Women's Consent: A Threat to Parents and Society in Medieval Norway and Iceland?" in Lars Ivar Hansen (ed.), Family, Marriage and Property Devolution in the Middle Ages (Tromsø, Norway, 2000) p. 55.

20 Goldberg, “'For Better, For Worse',” p. 119.

21 Ibid, p. 91 . Certainly, in some medieval cultures, a woman's consent was meaningless. For example, Jenny Jochens has argued that in Old Norse culture, "normally a woman was not asked for her opinion of her future spouse and was not informed until later, at times not until the moment of the wedding." See Jenny Jochens, "'Með Jákvæði Hennar Sjálfrar': Consent as Signifier in the Old Norse World," in Angeliki E. Laiou (ed.), Consent and Coercion to Sex and Marriage in Ancient and Medieval Societies (Washington, D.C., 1993), p. 273.

22 Barbara J. Harris, English Aristocratic Women 1450-1550: Marriage and Family, Property and Careers (Oxford, 2002), p. 56. 
a woman coerced into marriage by an aggressive suitor may have seen herself as a victim of a crime. And yet she had few legal options available to her. Under the jurisdiction of the church courts, she too could plead a suit of force and fear in the hope of obtaining an annulment. But the church courts did not offer a wholly satisfactory solution to such an unconscionable act. Even when the courts granted an annulment, they made no effort to penalize the person responsible for forcing the marriage. Hence, while an annulment might rescue the victim from an unpleasant situation, he or she was deprived of the satisfaction of seeing the perpetrator punished. What is more, proving that a defendant had employed sufficient force might be an onerous task. ${ }^{23} \mathrm{~A}$ coerced marriage might have become consensual through either sexual intercourse (where physical violence was not necessary to compel participation) or prolonged cohabitation. The former, of course, involved further complications. Late medieval English society espoused a Galenic theory of conception, in which both man and woman contribute seed emitted at the time of orgasm. Medieval society construed pregnancy as explicit evidence of female consent to sexual intercourse, because it believed conception required female orgasm. ${ }^{24} \mathrm{~A}$ victim of rape or coerced marriage might be betrayed by her body and lose her case in court as a result. The church courts also defined evidence of prolonged cohabitation. According to the canonists, even in the absence of any physical relationship, cohabitation for the period of a year and a half demonstrated an implied consent. ${ }^{25}$ With such strict guidelines, a victim of coerced marriage might have found a suit in ecclesiastical court a complicated and unrewarding process.

The royal courts also failed to offer a viable solution to victims of coerced marriage. The plight of the three petitioners before Chancery, with which this paper began, demonstrates that coerced marriage fell through the cracks of the common law system. Chancery only addressed those cases without remedy by normal procedure in the common law courts. ${ }^{26}$ Thus, that these three women

${ }^{23}$ See Sara M. Butler, The Language of Abuse: Marital Violence in Later Medieval England (Toronto, forthcoming).

24 The belief that pleasure was a prerequisite for conception led to a number of interesting conclusions in the Middle Ages. For example, prostitutes were thought to be infertile because for them sex was work, not pleasure. See U. Ranke-Heinemann, Eunuchs for Heaven: The Catholic Church and Sexuality (London, 1990), p. 64.

25 R.H. Helmholz, Marriage Litigation, p. 91. This is a much more generous allowance than that afforded by the king's courts in the prosecution of abduction cases. According to the Statute of Westminster II, the victim of abduction had forty days in which to appeal her case. If the offence went unprosecuted for more than thirty days, the court understood the woman to have consented to the action. For a further discussion of this detail, see J.B. Post, "Ravishment of Women and the Statutes of Westminster," in J.H. Baker (ed.), Legal Records and the Historian (London, 1978), p. 158. For a discussion of "implied consent," see James A. Brundage, "Implied Consent in Intercourse," in Consent and Coercion to Sex and Marriage, pp. 245-56.

26 Women were more likely to turn to equity courts than common law ones for legal resolution. The particularly feminine nature of some problems may have highlighted the gaps in the common law system and necessitated a resolution outside the usual process. For a discussion of women's role in Chancery as petitioners, see Emma Hawkes, "'[S]he will . . . protect and defend her rights boldly by law and reason. . .: Women's Knowledge of Common Law and Equity Courts in Late-Medieval England," in Noël James Menuge (ed.), Medieval Women and the Law (Woodbridge, 2000), pp. 14561 . 
were compelled to turn to Chancery at all reveals the inability of the common law courts to address non-consensual marriage.

A shrewd victim of coerced marriage might have interpreted her predicament as rape, a felony that was punishable by death since at least the Statute of Westminster II (1285). ${ }^{27}$ Before this, a variety of penalties existed for the crime, among which monetary compensation to the victim was by far the most popular, physical mutilation the least. Rape prosecutions offered victims little hope for reprisal, however. Royal attempts following the statute to punish rape "utterly failed," for much the same reasons that felonies in general were punished only rarely in late medieval England. The punishment of felonious activities did not allow for gradations of guilt; thus, juries were hesitant to impose the death penalty when they believed such a harsh penalty was not necessarily warranted. ${ }^{28}$ Consequently, from the late thirteenth century onwards, successful plaintiffs in cases of rape commonly pleaded a suit of trespass in which the victim could at least hope to obtain reparation for the damage to her value on the marriage market. As Roger Groot has argued, medieval Englishmen and women perceived such a resolution to be much more appropriate than physical punishment. ${ }^{29}$

What is more, medieval attitudes towards rape probably complicated contemporary perceptions of force. As the evidence of rape prosecutions suggests, medieval society perceived marriage as a suitable resolution in cases of rape. In fact, it has been argued that medieval Englishmen and women understood rape as a "prelude to marriage" in situations where the bride-to-be demonstrated reluctance to conclude the negotiations. ${ }^{30}$ Patricia Orr astutely notes that while such a settlement "was uncongenial to modern thinking," it "may have made good economic sense to the women concerned; it helped them to guarantee their marriageability." 31 In a society that prized virginity, particularly in women, a victim of rape had a lower value on the marriage market. Thus, if a woman were

27 Since Kelly's "Statutes of Rapes and Alleged Ravishers of Wives," the date at which rape became a felony is at some debate. Kelly provides very convincing evidence to suggest that the statute of Westminster II (or l, for that matter) had nothing at all to do with rape (only ravishment, or even more accurately, spousal desertion), and that in fact rape may have been regarded as a felony for a long time before this. See Henry Ansgar Kelly, "Statutes of Rapes and Alleged Ravishers of Wives: A Context for the Charges against Thomas Malory, Knight," Viator, 28 (1997), pp. 361-419.

28 For example, if a neighbour raped a woman after a visit to the local tavern where the two had been drinking and flirting together, was he as guilty as the stranger who stalked and raped an eightyear-old child? Both men had committed acts punishable by death, even though contemporary perceptions deemed only the latter to be responsible to that degree. See Harold Schneebeck, "The Law of Felony in Medieval England from the Accession of Edward I until the Mid-fourteenth Century" (Ph.D. dissertation, University of lowa, 1973), p. 463.

${ }^{29}$ Roger Groot, "The crime of rape temp Richard 1 and John," Journal of Legal History 9 (1988), pp. 325, 332.

30 Barbara A. Hanawalt, Crime and Conflict in English Communities 1300-1348 (Cambridge, 1979), p. 106.

31 Patricia Orr, "Men's Theory and Women's Reality: Rape Prosecutions in the English Royal Courts of Justice, 1194-1222," in Liam O. Purdon and Cindy L. Vitto (eds.), The Rusted Hauberk: Feudal Ideals of Order and Their Decline (Gainesville, 1994), p. 138. See also, Guido Ruggiero, The Boundaries of Eros: Sex Crimes and Sexuality in Renaissance Venice (New York, 1985), pp. 96-101. 
able at least to marry her rapist, she guaranteed her future economic prosperity. Orr's assessment is supported by the mid-thirteenth-century legal treatise attributed to the royal justice Henry Bracton. The treatise deliberately made a distinction between virgins and other victims of rape. It argued that while the penalty for rape was death or blinding, the courts might mitigate the punishment if the virgin chose to claim her assailant in marriage. ${ }^{32}$

Marriage as reparation for rape victims enjoyed a long existence in English society, dating back to the law codes of the pre-Norman era. The law courts of medieval England adopted this custom and, by the thirteenth century, even the church had softened its views of the practice. ${ }^{33}$ Although victims of rape did not resort regularly to marrying their rapists, the custom was common enough in medieval English society for historians to suggest that it was a socially acceptable answer to an undesirable problem. ${ }^{34} \mathrm{It}$ is noteworthy that this practice was not exclusively English. As Nicholas Davidson has observed, Italian cities like Ceneda and Mantua in the same period also "required rapists to marry or dower their victims - nothing more, in other words, than the obligation normally imposed on men who had deflowered a virgin with her consent." 35

A society that approves of marriage as a suitable solution to rape blurs the line between consent and coercion. The distortion of these boundaries is captured best in the 1355-56 case of Schipyn $c$. Smith from the York cause papers. Witness for the plaintiff Margaret Theker recounted her version of the exchange of vows ${ }^{36}$ between Maud Schipyn and Robert Smith.

\begin{abstract}
And she saw through the door of said basement how Robert pushed and pulled Maud into his house towards a place which is called Kowhos in English, and there he attempted to know her carnally. And then Maud said, "Our goddes forbode that
\end{abstract}

32 Henri de Bracton (ed. and trans. Samuel E. Thorne), De Legibus et Consuetudinibus Angliae (2 volumes, Cambridge, 1968), II, p. 417.

${ }^{33}$ Before the thirteenth century, the church actively campaigned against the marriage of rapist and victim. Gratian's Decretum is the first evidence of a change in perspective, and represents a gradual realisation that this tradition was too ingrained in secular practice to extirpate. See James A. Brundage, "Rape and Marriage in the Medieval Canon Law," in his Sex, Law, and Marriage in the Middle Ages (Hampshire, 1993), pp. 73-74.

${ }^{34}$ John M. Carter, "Rape in Medieval English Society: The Evidence of Yorkshire, Wiltshire and London, 1218-76," Comitatus 13 (1982), p. 47; Orr, "Men's Theory and Women's Reality," p. 139; Ruth Kittel, "Rape in Thirteenth-Century England: A Study of the Common-Law Courts," in D. Kelly Weisberg (ed.), Women and the Law: A Social Historical Perspective (2 volumes, Cambridge, 1982), II, p. 107. Here, it should be noted that some historians have argued that marriage might have been the objective of some rape suits. Accusations of rape levelled at a lover might ironically facilitate the marriage process when dealing with disapproving parents. See Brundage, "Rape and Marriage in the Medieval Canon Law," p. 74

${ }^{35}$ Nicholas Davidson, "Theology, nature and the law: sexual sin and sexual crime in Italy from the fourteenth to the seventeenth century," in Trevor Dean and K.J.P. Lowe (ed.), Crime, Society and the Law in Renaissance Italy (Cambridge, 1994), p. 84.

$36 \mathrm{It}$ is important to note that all that was required for a valid marriage in the medieval period was an exchange of vows in the present tense (for example, "I take you as my wife."). 
you should have the power to know me carnally unless you will marry me." Robert answered, "Behold my oath that if I take anyone to be my wife I shall take you if you will yield to me." Maud answered, "Behold my oath that I will be at your disposal." And Robert took her in his arms and threw her to the ground in le Kowhos and knew her carnally. ${ }^{37}$

Maud's intent in pursuing an exchange of vows (and, thus, creating a valid marriage) clearly was to make the best of a bad situation. Yet, not six weeks after the event she appeared before the archbishop to attest the marriage that Robert now vehemently denied had taken place. To the modern observer, what is probably most astonishing about this case is not only Maud's desire to stay married to such a man, but also the court's utter failure to address the manner in which the marriage came about. With or without the exchange of vows, Robert's violent and abusive treatment of Maud all too closely resembled rape. ${ }^{38}$ This testimony, however, reveals the sometimes ambiguous distinction between consent and coercion in medieval England, creating a legal environment in which victims of rape might not easily prove their allegations. 39

The English church also shared jurisdiction in the crime of rape, and thus may have seemed a viable option for a victim of coerced marriage in a suit of rape. In general, rape victims exercised this option rarely, owing to the church's unique definition of the crime. To plead a suit of rape in the ecclesiastical courts of medieval England, one had to meet four stringently enforced qualifications: force, absence of (the victim's) consent, coitus, and abduction, the final key element harking back to a time when rape and ravishment had been indistinguishable at law. 40 This rigid interpretation of rape immediately excluded many women who may genuinely have believed they had been raped. A woman violated sexually in her home or even down the street from her home was incapable of meeting the church's requirements for abduction and therefore, in the canonists' perspective, had not been raped. ${ }^{41}$ No wonder medieval Englishwomen preferred to take their chances in the king's courts. Moreover, royal courts provided either reparation or capital punishment; the church courts offered excommunication,

${ }^{37}$ BIY CP. E 70-6 (1355-56).

38 However, coercion was not the reason why Maud appeared in court, thus the church did not need to address the violent beginnings of this relationship.

39 See Corinne Saunders, "Woman displaced: rape and romance in Chaucer's Wife of Bath's Tale," Arthurian Literature, 13 (1995), pp. 115-31.

${ }^{40}$ Brundage, "Rape and Marriage in the Medieval Canon Law," p. 67. For a good discussion of the lasting nature of the heritage of rape as theft see Richard W. Ireland, "Lucrece, Philomela (And Cecily): Chaucer and the Law of Rape," in Timothy S. Haskett (ed.), Crime and Punishment in the Middle Ages (Victoria, 1998), pp. 37-62.

41 Given that "[s] exual offenses most commonly occurred in the victim's home," many victims of rape would have been prevented from suing a successful case before the church courts. James A. Brundage, Law, Sex, and Christian Society in Medieval Europe (Chicago and London, 1987), p. 493. 
amercements, at best the bishop's prison. ${ }^{42}$ For a woman seeking revenge or compensation, the king's courts seemed a more appropriate venue. ${ }^{43}$ In the case of a victim of coerced marriage, however, a suit of rape in the courts Christian would have been sadly out of place. The canonists contended that a wife was not amenable to rape because a woman gave her consent to any future sexual relations when she agreed to marry. ${ }^{44}$

A victim of coerced marriage, then, seemingly had few options in either the ecclesiastical or common law courts. A suit claiming the canonical impediment of force and fear in the courts Christian was a partial solution. Although it did not punish the attacker for his actions, at the very least, with this suit, a woman could have her marriage annulled and hope to remarry.

\section{The Law in Practice: \\ Part 1. Coerced Marriage in the York Cause Papers}

Because judgements in cases of force and fear frequently did not survive the era, it is difficult to determine with any level of precision whether the officials of the church found the levels of coercion in these cases to be sufficient evidence of force. Certainly, because the plaintiffs' lawyers helped to construct a presentation of the case that would meet the court's requirements for an annulment, it seems likely that even officials of the church would find the level of coercion presented by these plaintiffs as excessive. More important still, the kind of evidence brought forward by witnesses for the plaintiff speaks to the beliefs of the medieval English public. Although the depositions of witnesses were structured by the questions put to them in court, their responses often provide unsolicited but pertinent details that hint at broader perceptions of marriage and coercion in general. Thus, an analysis of these cases from the York cause papers helps us to retrieve a more popular understanding of coercion.

In 1443 Christian, the widow of Sir Robert Haryngton of Hornby, North Yorkshire, pleaded a suit of force and fear before the court at York and was awarded an annulment. ${ }^{45}$ Because her case was successful, the records offer evi-

42 Bishops' prisons were notorious for their high escape rates. See A.K. McHardy, "Church Courts and Criminous Clerks in the Later Middle Ages," in M.J. Franklin and Christopher HarperBill (eds.), Medieval Ecclesiastical Studies in Honour of Dorothy M. Owen (Woodbridge, 1995), p.173.

43 For a discussion of the effectiveness of the English church when dealing with felons, see McHardy, "Church Courts and Criminous Clerks in the Later Middle Ages," pp. 165-83.

${ }^{44}$ Brundage, "Rape and Marriage in the Medieval Canon Law," p. 70.

45 Moira Habberjam, "Harrington v. Saville: A Fifteenth Century Divorce Case," The Ricardian, 8 (1988), pp. 50-60. Habberjam's insightful article examines this case in detail and provides an interesting perspective of why women like Christian Haryngton (whom she compares to Margery Paston) chose to rebel. She not only investigates Christian's family status and the value of her inheritance in order to demonstrate her own standing in society, but also offers what most cases in court lack: a conclusion. After winning her case in court, Christian went on to marry Sir William Chorley. Within a year of receiving her divorce, however, both Christian and her new husband had died. 
dence of official and popular senses of coercion; at the same time, the case demonstrates clearly that the threat of force was ample to prove duress. When Christian's husband died without an heir, her brother-in-law was extremely disheartened at the prospect that her extensive property would no longer be part of the Haryngton family heritage and, more important still, that Harynton land would pass on to her for the duration of her life as dower. ${ }^{46}$ Concerned to do what was in the best interests of his family, Thomas Haryngton began scheming to hold on to the coveted property. He concluded that Christian should take as a second husband a person of his choosing, and abide by his arrangements to ensure that her family land might devolve to his own daughter Joan. His sisterin-law, however, did not share this concern for the well-being of the Haryngton family and balked at Thomas's proposal. Threatened with the loss of a sizeable property, Thomas turned to tactics of a more forceful nature. The ensuing marriage is evidence of the effectiveness of verbal threats.

Christian's witnesses maintained that, during the exchange of vows with Sir Thomas Sayvell of Thornhill (the groom chosen by her former brother-in-law, also the future father-in-law to Thomas's daughter Joan), the bride wept and had tears on her face. ${ }^{47}$ The testimony of Christian's brother-in-law himself nevertheless suggests that he saw nothing improper in his conduct, to which he freely admitted in court.

Concerning the coercion on lady Christian to contract this marriage, he said that on the Saturday before it took place he had come to York to meet Sir Thomas Sayvell and John, his son and heir, to discuss with them the betrothal of Joan, his daughter with John, the son and heir of the said John Sayvell, son and heir of the aforesaid Sir Thomas Sayvell, and at the same time he and Sir Thomas Sayvell broached the subject of a marriage between Christian Haryngton and Sir Thomas. And straight away he [Haryngton] went to Christian's room in her house on Bysschophyll and asked her if she would have Sir Thomas Sayvell as her husband. To which she replied tearfully that she did not wish to marry any man at that moment. So he said to her, If you consent to marry him for the honour of my name and family and friends, I will be a kind brother and true friend to you, but if you will not agree, then I will be your enemy ("inimicus") and take from you everything of yours, within my power. When asked what power he had or has over the lady

46 Upon the death of a husband, English law awarded the widow one third of her husband's property for the duration of her life (sometimes one half if the two had no children). For a discussion of dower rights, see Joseph Biancalana, "Widows at Common Law: The Development of Common Law Dower," Irish Jurist, new series 23 (1988), pp. 255-329.

47 "tristi et flebili vulto, sic. flendo et lacrimando." BIY CP. F 263 (1443). 
Christian, he said that he had and has the power to disinherit her from the major part of her lands and tenements, and, unless she would consent to marry Sir Thomas, he would disinherit her forever from the dower and jointure which she had from his brother, Sir Robert Haryngton, because she Christian had no deeds, writings, or other muniments to show for those lands and tenements which were solely within his jurisdiction ... And so, sad and tearful, she went to St. Mary's Church and said the marriage words. ${ }^{48}$

Thomas Haryngton understood that without his threats (and the ability to carry them through), he would have been incapable of obtaining his sister-in-law's consent to marriage. Nevertheless, he demonstrated no remorse for his behaviour, nor did he give any indication that he understood his actions to be immoral or unlawful. His position in this matter shows just how unclear were contemporary perceptions of coercion. An annulment on the grounds of force and fear required the use of excessive compulsion, but when parents and guardians frequently employed threats and physical violence to produce consent, where did one draw the line between persuasion and coercion? As Christian's brother-inlaw, Thomas Haryngton may well have believed his actions were justified.

According to the witnesses for the plaintiffs, Christian's situation rapidly deteriorated after the exchange of vows. On the way to Sayvell's estate near Wakefield, Christian was sufficiently distraught at the prospect of her wedding night that she collapsed in a faint. Her stupor was so prolonged that everyone in the party accompanying the couple to Sayvell's home was convinced she had died, and Sayvell was forced to send for his new bride's brother-in-law. They soon realized that she had not, in fact, expired from her distress, but her fatigue provided her with the ideal defence against Sayvell's romantic advances over the course of the next few days. Her excuse, however, quickly became stale and it was not long before Sayvell sent for Thomas Haryngton once again, angry because his wife adamantly refused to consummate their marriage (and, thus, threatened the validity of their marriage). Even after a second round of threats and intimidation from her brother-in-law, Christian was unwilling to go through with intercourse and she fled from her husband's bed. Sayvell called Haryngton in on numerous occasions after this in the faint hope that his presence might incline her to rethink her position, yet Christian remained steadfastly determined not to treat Sayvell as her husband. The two ultimately reached a compromise of sorts: separate homes, separate villages.

In Sayvell's defence, at the very least, he did not stoop to physical violence to extract obedience from his rebellious wife (although he was not above bribery, as his promises of a $£ 40$ gift of silver and other goods might suggest). ${ }^{49}$ Yet,

48 As cited and translated by Habberjam, "Harrington $v$. Saville," pp. 51-52.

49 Of course, a gift from husband to wife would have been void at law, as both Christian and Sayvell probably knew. Since all his wife's personal property became his upon marriage, effectively he would have been making a gift to himself. 
Sayvell was not free of guilt in this matter. The frequency with which messengers travelled from the estate of Sayvell to that of Thomas Haryngton remind of us of his responsibility. Knowing that Christian's conniving brother-in-law had had a previous role in influencing his new bride, Sayvell seems to have had no qualms calling on his services repeatedly. The threats might have come from Haryngton's mouth, but no sentiments passed between Christian and Haryngton that Sayvell did not heartily endorse. In light of this dynamic double-teaming, Christian's perseverance is nothing short of admirable. Her social status and wealth best explain both her obstinacy and Sayvell's unwillingness to employ physical compulsion. As a Westmorlandshire heiress, Christian must have realized that she was indeed, as Moira Habberjam has described her, the "most coveted of marriage partners." 50 If her marriage with Sayvell fell through and her depraved brother-in-law carried out his threats, she might have obtained an equitable resolution in the king's court even without the appropriate documentation. ${ }^{51}$ This knowledge must have buttressed her decision to resist. For the same reason, Sayvell might have found it difficult to justify the use of physical force. While some people may have failed to recognize the inequity of a marriage achieved by verbal threats, violence, and physical injury were more easily identifiable components of coercion. Intimidation of this nature likely would have elicited a response from Christian's peers. In this context, Sayvell's refusal to resort to physical cruelty seems less praiseworthy than calculating.

In her study of this case, Moira Habberjam reaches a conclusion that, while ostensibly reasonable, requires a more profound examination. She proposes that

[O]ne might consider this episode from the viewpoint of Thomas Harrington, whose public career suggests that he was a fairly typical example of the 'strenuus' northern gentry of the period. To him, Christian must have proved herself a most unsatisfactory addition to the Harrington family, having outlived her husband after neglecting to provide him with heirs. In such circumstances it was unquestionably his duty, as head of the family, to try to dispose of Christian's property to the best advantage of Harrington heirs, and that he allowed her personal inclinations to override the claims of dynastic advancement would suggest that he was more chivalrous than many another. 52

50 Habberjam, "Harrington v. Saville," p. 56.

${ }^{51}$ Although widows frequently were required to fight in court in order to obtain their dowers, the common law did provide abundant protection of widows' dowers and it seems likely that a woman in Christian's position would have been able to put together a strong case to retrieve her dower lands. See Sue Sheridan Walker, "Litigation as Personal Quest." To prove her claim to lands held by jointure, however, Christian most certainly did need to provide documentation before the courts, and thus might have been incapacitated without them.

52 Ibid., pp. 59-60. 
From Haryngton's perspective, his actions were justifiable. Robert and Christian's marriage had been a failure in terms of family alliances and property interests. None the less, to imagine "that he was more chivalrous than many another" is a much more damning statement of late medieval society than is warranted. Certainly, the evidence of family involvement suggests that some level of coercion was acceptable; but the success of this case at York confirms the inappropriateness of this degree of force. That Christian was capable of finding eleven witnesses (a fairly large number for the time) to stand up in court and testify that the force employed by Haryngton and Sayvell had been unreasonable also suggests that popular consensus sided with the decision of the court. Habberjam's conclusion, however, is instructive and, once again, underscores the use of coercion in various forms in the marriages of the English gentry.

Because Christian Haryngton was successful in her suit, her case sheds some light on the general guidelines employed by the church courts of late medieval England in determining what constituted enough force to "weaken a stable man" (or woman, in this case). While Chobham may have envisioned a situation in which the coercion was exclusively, or at least primarily, physical in nature, the circumstances of Christian Haryngton's marriage to Thomas Sayvell would suggest that corporeal harm was not a necessary component. Additional features requiring consideration probably bolstered Christian's case. Not only was her reluctance vocal and widely known; she also persisted in her defiance even after the nuptials, a fact to which the ladies of the Sayvell household could testify. In the absence of consummation, the union was questionable at best and easily dissoluble without debasing the sacrament of marriage. 53

The case of Alice Townley and Roger Talbot (1477), however, reveals that sometimes coercion might adopt a much more virulent form. When Roger Talbot of Salesbury on the Ribble (Lancashire) determined that he was going to marry Alice Townley (with or without her consent), he chose the middle of the night as a convenient time to surprise his bride-to-be. In order to convince her of his worthiness as a groom, he dragged Alice from her home, forced her to undress and then threatened to cast her into the river and drown her if she refused to give her consent. Ralph Briscoll of Whalley parish, who was alerted to the scene by Alice's wailing and then witnessed the episode through a hole in the wall, noted how Roger warned Alice of the serious consequences of a refusal, saying that unless "thou will consent to be wedded with me 1 shall cast ye in the pole of Sailewode." 54 This was followed some time after with the threat that unless "thou consent to be wedded with me I shall stik the[e] with this dagar."

53 Throughout the high Middle Ages, canonists debated the necessity of consummation for a valid marriage. While Pope Alexander III was instrumental in making marriage dependent on consent alone, consummation continued to be a concern for ecclesiastical officials and litigants alike. This is obvious in the approach adopted by canonists to consummation and coerced marriage in general. Requiring that the sexual act be accomplished with violence would seem to suggest that the centrality of consummation to the validity of a marriage continued within the courts Christian (and among the lay folk of medieval England) irrespective of Alexander's definitive stance.

54 For a more modern audience, "th" has been used in place of all " $p$ " in the records. 
According to Edmund Richardson, a fellow peeping Tom, Roger knotted a towel around Alice's neck, declaring "withoute thou will consent to have me to thi husband and that I may lye with ye I shall throtill the[e] with this tewel." Despite the persistent threats and manhandling, Alice stubbornly refused to succumb to his wishes because of their widely known consanguinity (known well enough that a number of her witnesses produced family trees along with their depositions). ${ }^{55}$ With the towel twisted around her throat, no doubt beginning to cut off her air circulation, she cried out: "trewly to dy th[ere]fore, I will never consent to you for we er overe nere sybbe." Alice finally gave way under the strain after being beaten by one of Talbot's associates and abducted to Ribchester. ${ }^{56}$

Having at length obtained Alice's consent, Talbot needed only to find a priest to solemnize their marriage. This mission led him to the window of the local parish priest, a man named Roger Deane, at dawn the morning after the beating, eliciting the chaplain's unhappy query, "Sir, what make ye here thus tymly?" Roger replied, "I am comen hider to be wedded with this gentilwoman and I pray you that ye will do the sacrement." Incensed and more than a little bit fearful, the priest extracted himself diplomatically from a compromising situation. He responded, "Sir, I pray you hold me excused. I dar not wed you for it is agayns the law. Ye ar not married in the kirk [church] and also ye ar within the grades of marriage, and therefore trewly I will not wed you ne be present at your weddyng." Faced with the chaplain's obstinacy, Talbot turned to Mersend, a friar he had elicited to witness the exchange, and ordered him to perform the marriage ceremony between him and Alice. The friar accompanied his escort to the chapel where he solemnized the marriage of Roger and Alice without the requisite reading of the banns (a detail noted by several of the witnesses), and where Alice was reported to have wept throughout the ceremony.

Married life for Alice was not a vast improvement over the courting process. Her husband beat her frequently, incarcerated her, and forced her to live in isolation from family and friends. In fact, one witness noted that Roger did not permit Alice to speak with any friend or relative during the entire time of her marriage (described as lasting "part of a year," spent first at Salesbury, then Ribchester, and lastly Bashall). When she was finally able to escape her domestic prison, she made her way to the home of Agnes Houghton of Pendleton. In the presence of Agnes, Thomas Ryley, Jered Hoghton de Staynhirst, and others, Alice declared, "Cosyn, I have bene holden in prison and sore bet as ye shall see and I am now getyn away fro Roger Talbot, I thank God, and I will never com with him duryng my lyfe, wherfore I pray you help to bryng me to York." Her family and friends abided by her wishes, and she proceeded to testify to the beatings and cruelties inflicted upon her by Roger, baring the wounds on her arms, shoulders, and legs as evidence, and to swear that she had in no way consented to marriage with him. Soon thereafter, Alice began proceedings in the church courts for an annulment.

55 In the Middle Ages, marriage was prohibited for those related within four degrees (that is, as close as third cousins).

56 BIY CP. F 257 (1477). 
The case of Alice Townley is a manifest example of coercion. Roger not only skilfully employed verbal threats, but also physically abused Alice and held her against her will. From the wounds attested by her deponents and the extreme nature of Roger's threats, Alice's life was in danger. It is unfortunate that Alice's libel, recording her plea and detailing the accusations against Talbot, has not survived, nor has the court's sentence for this case. Had Alice chosen to sue her case on the grounds of an impediment of force and fear, the courts probably would have returned a sentence in her favour. Yet, because Alice's witnesses pass a good deal of time testifying to the gradations of consanguinity between her and Talbot, it is possible that her case was not one of coercion at all, but instead a plea of consanguinity, also grounds for an annulment. The best explanation for such a choice is that consanguinity was a guaranteed course of action. While force and fear were difficult to define and subject to interpretation, grades of incest were traceable and proven easily. In this light, witnesses may have included mention of Alice's abuse and the intimidation of both clergymen primarily to absolve those parties of any sin in contracting and officiating over the marriage. Alice's witnesses affirm that neither was a willing participant and that the entire blame for the illicit marriage belonged to Roger. Furthermore, witness depositions attest that Alice and Roger both were aware of their consanguinity before the exchange of vows and that, in any event, Alice did not wish to remain in the marriage. Official record of both facts might have been useful evidence should Roger choose to appeal the case to Rome in the hope of receiving a papal dispensation. Although rare, married couples who, belatedly, became aware of such an impediment sometimes requested papal permission to remain together because of their enduring affection towards each other. The testimonies of Alice's witnesses, however, provided firm proof that, in these circumstances, a dispensation was neither required nor desired. Why should Alice have brought her case forward as one of consanguinity when armed with such an unarguable case of coercion? Without more documentation, it is difficult to draw any conclusions. However, the duality of her allegations hints that she (or her lawyer) was not entirely confident that the evidence of coercion in itself would meet the court's stringent requirements.

Why would Roger Talbot have wished to marry Alice against her will? Given the measures required to convince her to marry, the couple (obviously) was not destined for wedded bliss. In this respect, the case of Christian Haryngton discussed above helps to shed some light on the situation. When Thomas Haryngton resolved to arrange a marriage for his sister-in-law that would keep her land in the family, his decision reflects a popular practice among the gentry of later medieval England. Marriages designed to protect a family's property or to aggrandize its current property holdings were the objective of every family of landed wealth. As a result, marriages were not casually made. Among those with property, "the language of the marketplace" was used commonly "to describe the negotiations and exchanges involved in finding husbands for their children." 57 Thus, Thomas Haryngton was merely trying to carry out the

${ }^{57}$ Harris, English Aristocratic Women 1450-1550, p. 44. 
original aims of the marriage between his brother and the Westmorlandshire heiress (a union that might have been profitable for the Haryngton family had the couple produced an heir). Here, we should not assume that economic interests necessarily conflicted with love interests. Many women would have been inclined to marry within their own class anyway, chiefly because their social interactions were restricted to a small circle of acceptable suitors. This did not preclude the possibility of love; as James Brundage has argued, "[d]espite the preoccupation with political and economic matters that often dictated marital choice ... many of these marriages ripened into warm and affectionate personal relationships." ${ }^{58}$ In the case of Christian Haryngton, however, economics and love were not one and the same. Alice Townley may have found herself in a similar situation. Given the absence of support from a network of male family members, it seems logical to conclude that Alice had recently become an heiress to her family property, and thus any marriage she contracted would pass a substantial portion of land permanently out of the Townley family. Roger's decision, then, would have been motivated less out of an undying affection for Alice than a desire to keep the family land intact.

At least Roger did not attempt to strengthen his marriage by compelling his reluctant bride to consummate their union. The same cannot be said for John Dale, who adopted a similar approach to win the hand of Agnes widow of Hugh Grantham, brewer and servant of William Pountfret of York. In the month of July 1411, not four months after her husband's death, while on her way to have dinner at the home of William Feryby, master of St. Leonard's Hospital at Acomb Grange, York and a long-standing client to whom she often brought ale, Agnes was attacked and abducted. Accompanied by her son Thomas and her servant Alice Rayner, she was ambushed in the fields of the grange by the royal highway by John Dale, Feryby's notary, who arrived with Thomas Wakefeld and Robert Kyrkham. Hearing the threats of death and bodily harm directed towards Agnes, her son and servant tried their best to fend off the attackers, but Wakefeld quickly asserted control over the situation. Brandishing a dagger, he laid violent hands on Agnes's son and warned him under pain of death to leave the vicinity immediately, which he did, hoping to find help for his mother. For her part in the defence, Alice was struck and gravely wounded. Seeing the injuries befall her son and servant, Agnes did not dare resist. The men took her against her will on the back of John Dale's horse, all the while crying for help. Dale and his two accomplices brought Agnes to lodging in Wighill and detained her there. They tied her up and treated her violently, and it was not long before John Dale forced her to engage in sexual intercourse ("Johannes carnalem copulam extorquisset ab eadem"), an act he was to repeat a number of times in the hopes of wearing down her resistance. Wighill was not the last stop for Agnes and her kidnappers. From there, the men took Agnes to the forest of Knaresborough and then later to the vill of Healaugh where, trembling and tearful, she was forced to exchange words of marriage with John Dale. 59

${ }^{58}$ Brundage, Law, Sex, and Christian Society in Medieval Europe, p. 497.

${ }^{59}$ BIY CP. F 36 (1410). 
Agnes ultimately managed to escape John Dale. She appears to have gone on with her life, although, fearing another attack, she refused to take up residence in her former home in the parish of St Michael le Belfrey. Instead, she moved into the home of William Pountfret (seemingly her employer, although in what capacity it is unclear), in the parish of All Saints, Pavement. ${ }^{60}$ Given her horrific story, it is remarkable that when Agnes showed up in court before the archbishop it was not to plead a suit on the grounds of duress. Instead, Agnes appeared in response to a suit by the very same John Dale, who was attempting to get the marriage enforced. Although Agnes wanted the marriage annulled on grounds of force and fear, like Alice Townley's before her, her defence did not rely exclusively on coercion. While Agnes offered evidence of the rape and forced exchange of vows, the pinnacle of her argument was that she could not marry John Dale because she was precontracted to John Thornton, with whom the many witnesses agreed she had an affectionate friendship ("amicitia") long before John Dale entered her life. ${ }^{61}$ Agnes found herself in a difficult situation. With this suit, Agnes's presence at the Feryby grange is cast suddenly in a new light. Dale and Feryby may have staged her stay at the grange with the intention of providing Dale the opportunity to carry out his sinister plan. With such powerful rivals, a defence of precontract might have seemed the most assured alternative. None the less, the court's willingness to listen to numerous accounts of Agnes's abduction and its final decision to uphold the marriage of Agnes to John Thornton indicates it took Dale's violence and abuse of Agnes into serious consideration. ${ }^{62}$

The success of Grant $c$. Seil (1499-1500) illustrates what may have been the most prudent method of pleading impediment of force and fear when compelled into marriage by a suitor. Margaret Grant alleged that not only had a physically abusive bully forced her into marriage, but also her own parents had supported his endeavour. According to one witness, John Clerk of the parish of Pikehall, Margaret's parents ejected her from the family home when they learned that she did not intend to marry John Seil, a known misogynist who was reported to have complained bitterly for years about the ingratitude of women. Without her family's protection, Margaret was at once vulnerable to Seil's prurient advances. To entice Margaret into a brief exchange of vows and a little carnal copulation, John seized her and forced her to ride with him from Pikehall to Snape where he beat her severely with a wooden staff three or four inches in thickness. In the end, out of fear for her life or further bodily harm, Margaret gave her consent, but it is

${ }^{60}$ The decision of Agnes Grantham to move into her employer's household has been examined in detail by Cordelia Beattie in "A Room of One's Own? The Legal Evidence for the Residential Arrangements of Women Without Husbands in Late-Fourteenth- and Early-Fifteenth-Century York," in Noel James Menuge (ed.), Medieval Women and the Law (Woodbridge, Suffolk, 2000), pp. 41-56.

${ }^{61}$ Agnes's defence goes a long way towards substantiating Charles Donahue, Jr.'s theory that medieval marriage was not as permanent as one might think, "because everyone, or at least many people, could come up with a precontract." Charles Donahue, Jr., "A Legal Historian Looks at the Case Method," Northern Kentucky Law Review, 19 (1991), p. 27.

62 In the end, this case was appealed to the Holy See for resolution, although the final decision in this matter is unknown. 
reported that she wept sorrowfully ("lamentabiliter plurabit") throughout the exchange. ${ }^{63}$ Unfortunately, the final sentence in this case has not survived. The plaintiff's strategy, nonetheless, is very instructive. By implying the collusion of her family, Margaret was capable of presenting a case of coerced marriage that made sense to the courts. More accustomed to parental, rather than spousal, force, the courts may well have been more sympathetic to such a recognizable case of abuse.

Perhaps most intriguing about the case of Margaret Grant in particular, but also those of Agnes Grantham and Alice Townley, is how closely the circumstances described by the witnesses adhered to the canonical requirements for rape. According to their deponents, the duress experienced by both Margaret Grant and Agnes Grantham readily fulfilled all the church's expectations of a victim of rape. In the case of Alice Townley, the key element of coitus was absent from testimonies and yet, otherwise, all the essentials (including abduction) were present. Moreover, witnesses all described Margaret, Agnes, Alice, and Christian as demonstrating the kind of resistance canonists expected of rape victims: a public and vocal display of tears. ${ }^{64}$ Whether unconscious or deliberate, these plaintiffs associated marriage coerced by a suitor with the crime of rape, even though the royal courts prevented the victim from appealing her unwanted husband of the crime.

Even so, the records reveal a gap between the theory and the practice of the law. Provisions for the impediment of force and fear appear to have been an ideal means of dissolving a marriage contracted by force at the hands of a determined suitor. Yet, the suits involving Agnes Grantham and Alice Townley, who preferred not to rely on evidence of coercion alone, suggest that English women might have thought otherwise. In particular, the instance of Agnes Grantham, who chose to do nothing until compelled into action by Dale's suit, supports this contention. Victims of parental or familial pressure, rather than of spousal coercion, claimed force and fear much more readily. This disparity may reflect the urgency of the matter. A woman who endured threats and abuse from a barbarous suitor-turned-husband likely was living in daily fear for her life, whereas a young girl forced into a marriage by her parents might have found her new husband of the same mind. Thus, a victim of coerced marriage, like Agnes Grantham or Alice Townley, was probably more concerned with escape than anything else.

Agnes Grantham's decision simply to ignore the issue, a decision that may seem incompatible to modern thinking, may have been a common approach. When Maud Barnesley and Richard Smyth appeared before the court of the Dean and Chapter in York in 1399, Maud reported that she had agreed to marriage with Richard only upon the threat of incarceration. Like Agnes, the circumstances that brought her before the court had nothing at all to do with a coerced marriage. Rather, Barnesley and Smyth were summoned before the court to respond to allegations of fornication (an indication that their marriage was not widely acknowledged within the community), and it was only Maud's response to the charges

63 BIY CP. F 308 and 295 (1499-1500).

${ }^{64}$ Brundage, "Rape and Marriage in the Medieval Canon Law," p. 69. 
that revealed that her consent to the marriage had been extorted by threat. If the court had not presented her for fornication, her case might not have come before the courts at all. ${ }^{65}$ Because sexual intercourse and prolonged association transformed a coerced marriage into a valid union, many women in Maud's position may have accepted their lot, assuming that their cases would be too difficult to prove in court. But it is important to acknowledge, once again, that these two cases were not exceptional. In 1390, Joan Monceaux, lady of Barmston in Holderness, was summoned before the archbishop at York to respond to John Carnoby's request that the court uphold their marriage. With three witnesses in his support, John argued that he had exchanged vows with Joan, followed by intercourse, and that Joan had on several instances confirmed the marriage in front of other witnesses. Joan's response was to deny heatedly the validity of the marriage. Her witnesses argued that her marriage was contracted under duress. Joan herself chose a slightly different tactic. Rather than present a defence of force and fear, she chose to focus on the disparity of rank between the two. Her witnesses confirmed that she was a lady of good standing with an annual income of 300 marks and some claim to royal blood. Her testimony implies the utter absurdity of a woman of her rank agreeing to marry a man whose estate simply could not compare. At this point, the case was dismissed due to three consecutive non-appearances by John Carnoby; thus, it is unclear whether the court might have been swayed by John's testimony. However, it is telling that, once again, seemingly a victim of coerced marriage chose to await litigation, rather than take the case to court herself. 66 In general, the reluctance of victims of coerced marriage to utilize the provisions of the court for annulment on these grounds is telling, and may offer insight into contemporary perceptions of nonconsensual marriage. Clearly, parental or familial force was a recognized problem within late medieval society; spousal coercion was not.

\section{Law in Practice: \\ Part 2. A Case of Coercion from the King's Courts}

In his investigation of the records of the king's courts of the late thirteenth and early fourteenth centuries, Robert Palmer uncovered the 1286 case of Medefeld $c$. Sandcroft, an enlightening case of coerced marriage, which demonstrates that the king's courts might offer some opportunity for legal assistance. The case also

${ }^{65}$ A very brief notation of this case appears in BIY M 2(1) f, fo. 30 . A similar notation also appears in the Dean and Chapter court book for the years 1387-1494, although the entry includes no additional detail. See BIY D/C AB 1, fo. 15. Incarceration might have been a useful tool of aggressive suitors. When Juliana Atwell of St. Nicholas parish contracted marriage with John Kyrkeby of Monkton in the mid-fifteenth century, it was also because he had imprisoned her at Sandholme until she agreed. This case appears in a Canterbury act book for the years 1459-63. See Canterbury Y.I., fo. 72 .

${ }^{66}$ BIY CP. E 179 (1390). This case has also been discussed at some length in Frederik Pedersen, Marriage Disputes in Medieval England (London, 2000), pp. 124-26. 
highlights popular disapproval of violence in courtship through the decision of the jury to inflict upon the attacker a heavy financial penalty for his actions.

In an assize roll from the year 1286, Medefeld c. Sandcroft recounts the story of a betrothal gone awry. Mary de Medefeld and Geoffrey Sandcroft were betrothed through mutual consent; but when it came time to make the arrangement more permanent Mary balked, and Geoffrey turned to the church courts to enforce his claim to marriage. Although the court sentenced in his favour, Mary refused to abide by its decision and at once initiated a suit in the courts Christian.

Rather than await the outcome of her suit, Geoffrey adopted a more aggressive stance. Knowing that an exchange of conditional vows might easily be transformed into a legally binding marriage through intercourse, he set off with Ralph de Sandecroft and Henry de Sandecroft in tow. With the blessing of the local parish priest, he borrowed a horse and rode off to kidnap his reluctant bride. He soon discovered that the task was not to be as easy as he had hoped.

Mary would not go quietly. She wrapped herself around a hawthorn tree, so that she was injured when they forcibly dragged her away. She then refused to ride, so they put her across the back of the priest's horse; she raised the hue and cry all the way to Sandcroft's brother's home... They had a room prepared there, complete with a bed; Sandcroft and Mary were closed up alone in the room together for five days. But, the jury reported, every time he laid hands on her, she screamed; Sandcroft's brother finally advised him to desist. Becoming somewhat worried by her intransigence, they insisted she make out a deed surrendering her right to implead them for their misconduct. Only then did they allow her to go. ${ }^{67}$

Geoffrey and his brother had miscalculated, however; Mary's knowledge of the common law was more than sufficient to know that a deed extracted by force was not binding. She took her case to the king's court and sued for forcible abduction and imprisonment, demanding $£ 100$ in damages, which the court, in turn, awarded.

To the modern reader, Geoffrey's attempt to win the hand of Mary de Medefeld is both deplorable and bizarre. One cannot help but ponder what might have driven him to embark on this peculiar course of action? More serious still, how, in good conscience, could the parish priest have counselled Geoffrey to kidnap and incarcerate a woman with whom he hoped to spend the rest of his life? Palmer solemnly notes that justices intended the steep penalty as "a clear warning that the king's court would not tolerate the heavy-handed wisdom approved by the local priest." 68 The priest's readiness to abet Geoffrey in this offence, also,

67 PRO JUST 1/832, m. 9, as discussed by Robert C. Palmer, "Contexts of Marriage in Medieval England: Evidence from the King's Court circa 1300," Speculum, 59 (1984), p. 66.

68 Ibid. 
is somewhat alarming; while it is difficult to imagine that this was a familiar method of handling nuptial cold feet, one cannot help but wonder what counsel local parish priests offered spurned suitors.

Mary's stubborn resistance throughout her imprisonment and her willingness to petition in not one but two courts, confirms that she was a woman of rare independence and strength of character. While Mary possessed the courage to resist Geoffrey's advances during her captivity, how many women would have succumbed?

The requirements of the church for awarding an annulment on the grounds of force and fear help to clarify the suit that Mary brought in the king's court. The account of Medefeld $c$. Sandcroft states explicitly that Geoffrey had not violated Mary physically. Palmer interprets this detail as an indication of Geoffrey's sound judgement, that he "had at least known enough not to endanger his life by committing rape." 69 The official record of this fact was presumably even more important to Mary. The likelihood of a trial jury convicting Geoffrey of rape was very small. With her appeal pending before the church court, however, Mary's concerns were grave. If she wished to build her case for an annulment on the grounds of coercion, she needed to be able to assert that the two had not (at least, willingly) consummated the union. The official statement of this fact amidst the records of the king's court provided Mary with solid proof that she could enter into evidence before the archbishop's court.

The royal court's award of $£ 100$ in damages, as Palmer contends, speaks to a certain distaste for Geoffrey's oppressive and clumsy approach. If the church courts decided in Mary's favour, the award effectively would bankrupt all three defendants. Given Geoffrey's actions since the couple first appeared in the ecclesiastical courts and the success of Mary's case before the king's justices, financial ruin may have been the inevitable outcome for Geoffrey Sandcroft and his two acquaintances. The record of her case in the king's court alone provided documentation of all the necessary elements of a coerced marriage: non-consensual but violent abduction (without any sexual intercourse to heighten the sinful nature of the crime or implicate the victim). With such a sound case built against him, Geoffrey's chances of success were few. If the archbishop chose not to support Mary in her cause, however, the award was meaningless. As Mary's husband, Geoffrey would be both debtor and recipient of the $£ 100$ award; he would be in the unique position of paying himself for Mary's damages. This situation raises an intriguing question: did the king's justices award such an astounding sum of money to the plaintiff on the assumption that he need never pay it? It is unfortunate that Mary's appeal to the court of Arches has not survived among the court's records of matrimonial litigation. Without it, it is difficult to assess with any certainty whether the king's justices intended the award as a slap on the wrist for a husband's ill-conduct, or whether it was a recognition of a serious transgression of Christian ethics and communal mores. The only evidence to support the 
latter interpretation is the fact that the king's court accepted Mary's suit for trespass rather than dismiss it out of hand on the grounds that a wife could not sue a case at common law against her lawful husband. Mary's success, then, confirms Palmer's suspicions that at least "during an appeal against a judgement declaring her to be married, a woman still retained her rights." 70

The case of Medefeld $c$. Sandcroft serves as an important reminder to historians about the resourcefulness of medieval Englishwomen. Mary de Medefeld possessed a sufficiently profound knowledge of the law to realize that her case against Geoffrey was twofold: not only had Geoffrey sinned by dishonouring the sacrament of marriage, his actions were also civilly wrong. Most victims of coerced marriage were incapable of receiving compensation for their suffering. Mary, however, shrewdly realized that she might harness the independent jurisdictions of the courts of late medieval England to guarantee both an annulment and reparation..$^{71}$ The courage and determination of Mary de Medefeld brings this investigation full circle, returning us once again to the question of what options for legal resolution were available to a victim of coerced marriage. Where Mary was able to obtain reparation for the crimes committed against her, her case did not represent the norm. Because marriage conferred on husbands' virtually unlimited control over their wives' property, women in medieval England sometimes became the victims of this unique form of violence. Although medieval society recognised the vulnerability of women in this respect, medieval English law (both common and canon) presented few options for a victim of coerced marriage. What is more, the law in practice seems to have blurred the distinction between consent and coercion. The cases under examination in this study highlight a wide range of violence: from threats of destitution and death to violent rape. That levels of coercion were of such an extreme nature suggest that lawyers and litigants alike believe such indisputable evidence of violence was necessary to win a suit at law. At the same time, the reluctance of some women with legitimate causes to plead a suit of force and fear at all, hints that they feared the courts might have condoned the use of coercion. Medieval English society was largely uninterested in the punishment of overzealous bridegrooms. While parental force was a recognisable and relatively popular matter to pursue at law, spousal coercion was not. In this legal and social climate, victims of coerced marriage who actually used the law to annul their marriages or punish their attackers with financial penalties demand our full admiration for their courage and ingenuity.

St. Mary's University, Halifax, Nova Scotia

70 lbid.

7 Mary de Medefeld's knowledge of the law and its various jurisdictions cautions us to consider the larger picture in such an investigation. Legal historians frequently define themselves by the variety of law they study: canon law, common law, or custom. For the Englishman or woman of the later medieval period, these various jurisdictions were much more integrated than the separate categories of historians might suggest. Accordingly, a thorough study of any legal phenomenon in history requires an investigation of the entire legal system and not just one separate component, because while a matter might seem to be primarily spiritual to our eyes, an angry medieval litigant might have perceived the situation in an entirely different manner. 
Copyright of Canadian Journal of History is the property of Canadian Journal of History and its content may not be copied or emailed to multiple sites or posted to a listserv without the copyright holder's express written permission. However, users may print, download, or email articles for individual use. 